\title{
ORGANIZUOJANTI PNEUMONIJA. KLINIKINIS ATVEJIS
}

\author{
Ernesta Bagurskiené $\dot{1}^{1,3}$, Rolandas Zablockis ${ }^{2,4}$ \\ ${ }^{I}$ Vilniaus miesto klinikine ligonine, ${ }^{2}$ Vilniaus universitetas, Klinikinès medicinos institutas, Krūtinès \\ ligu, imunologijos ir alergologijos klinika, ${ }^{3}$ Vilniaus universitetas, Klinikinès medicinos institutas, \\ Vidaus ligu, šeimos medicinos ir onkologijos klinika, ${ }^{4}$ Vilniaus universiteto ligonine \\ Santaros klinikos, Pulmonologijos ir alergologijos centras
}

Raktažodžiai: organizuojanti pneumonija, obliteracinis bronchiolitas su organizuojančia pneumonija, vaistų sukelta intersticinè plaučių liga, pegiliuotas interferonas, virusinis hepatitas C.

\begin{abstract}
Santrauka
Organizuojanti pneumonija (OP) - intersticinè plaučių liga, kuriai būdingas ribotoje plaučių dalyje arba keliose atskirose vietose mezenchiminių proliferatų susidarymas alveolèse. Sergamumas šia liga nèra aiškus. OP gali būti nežinomos kilmès (kriptogeninè) arba susijusi su kita liga ar patologine būkle (sukelta medikamentų, toksinų, uždegiminių autoimuninių ligų, navikų, radioterapijos ir kt.). Ligos simptomai nespecifiški, gali pasireikšti subfebriliu karščiavimu, sausu neproduktyviu kosuliu, dusuliu. Dažnai klinikiné eiga lengva, retesniais atvejais progresuoja dusulys, kvèpavimo funkcijos nepakankamumas. Radiologiniai OP požymiai ịvairūs - aiškių ribų plaučių pritemimai (sutankèjimai) skirtinguose segmentuose ar skiltyse. Diagnozè patvirtinama morfologiškai ištyrus bronchoskopinès plaučių audinio biopsijos metu gautą medžiagą. Lengvais ligos atvejais gydymas neskiriamas. Sunkesniais atvejais OP gydoma gliukokortikosteroidais (prednizolonu ar metilprednizolonu), tačiau simptomai išnyksta bei rentgeniniai pokyčiai dažnai visiškai rezorbuojasi tik per kelis mènesius.
\end{abstract}

\section{Ivadas}

Virusinis hepatitas C - šių laikų pasaulinè problema. Viena iš galimų gydymo taktikų, gydant šią ligą - pegiliuoto interferono bei ribavirino derinys. Šių dviejų medikamentų derinys virusą sunaikinama iki 90 proc. atvejų [1]. Nors gydymo pasirinkimas potencialiai sèkmingas, ribavirino bei pegiliuoto interferono derinys gali sukelti nepageidaujamų poveikių - panašius ị gripą simptomus, citopeniją, depresiją, traukulius. Literatūroje plaučių pažeidimas nurodomas retai (bendras dažnis iki 1 proc.) [2,3], tačiau galimi ịvairūs pažeidimo tipai: plaučių sarkoidozè, intersticinis pneumonitas, organizuojanti pneumonija, obliteracinis bronchiolitas su organizuojančia pneumonija, skystis pleuros ertmèse, bronchinès astmos paūmèjimas ar ūminis respiracinio distreso sindromas [4].

Organizuojanti pneumonija $(\mathrm{OP})$ - intersticinè plaučiu liga, kuriai būdingas ribotoje plaučiu dalyje arba keliose atskirose vietose mezenchiminių proliferatų (Masoni kūnelių) susidarymas alveolèse [5]. Organizuojanti pneumonija gali būti nežinomos etiologijos (kriptogeninė) arba susijusi su kita liga ar būkle (žinomos kilmès). Rizikos veiksniai, galintys lemti OP: infekcija, sisteminès jungiamojo audinio ligos, uždegiminès žarnų ligos, vaistų (amiodarono, bleomicino, karbamazepino ir kt.) vartojimas, sergant kepenų ligomis, esant radiacijos poveikiui, lètinei aspiracijai, po organų transplantacijos, ịvairių formų leukemijai, limfomai, karcinomai, ¡̊kvėpus cheminių medžiagų ir kt.

Kriptogeninę OP būtina atskirti nuo žinomos kilmès (kitų ligų, vaistų) sukeltos OP. Auksinis OP diagnostikos standartas yra tipiški plaučių biopsinès medžiagos tyrimo duomenys.

Organizuojančios pneumonijos ligos prognozė palanki dažniausiai lengvesniais atvejais net ir negydant simptomai išnyksta, rentgenologiniai pokyčiai rezorbuojasi. Sunkesniu atveju (progresuojant kvejpavimo nepakankamumui, progresuojant rentgenologiniams pokyčiams) skiriamas gydymas steroidais (prednizolonu ar metilprednizolonu) - patologiniai pokyčiai dažniausiai išnyksta be liekamujų reiškinių.

Pateikiamas paciento, kuriam nustatyta dèl virusinio hepatito $\mathrm{C}$ vartojamų ribavirino ir pegiliuoto interferono sukelta organizuojanti pneumonija, klinikinis atvejis. Lietuvoje mes neradome publikacijų šia tema. Pasaulyje tokie atvejai aprašyti vos keli [3, 6-11]. Literatūros apžvalgos analizei naudota PubMed paieškos sistema, pasirenkant paieškos kriterijus: virusinis hepatitas $\mathrm{C}$, organizuojanti pneumonija, pegiliuotas interferonas, ribavirinas (angl. viral hepatitis 
C, organizing pneumonia, pegylated interferon, ribavirin). Literatūros apžvalgoje aptariami klinikinio pasireiškimo ypatumai, galimos gydymo taktikos, baigtys.

\section{Klinikinis atvejis}

$44 \mathrm{~m}$. vyras atvyko dèl neproduktyvaus priepuolinio kosulio, progresuojančio dusulio, subfebrilaus karščiavimo vakarais. Kosulys vargino apie 2-3 mėnesius, kreipèsi i š šimos gydytoją, skirtas gydymas ceftriaxonu $1 \mathrm{~g}$ x $2 \mathrm{k}$./d. (10 dienų ), nesant pagerèjimo, skirta ciprofloksacino $200 \mathrm{mg}$ x 2 k./d. Dusuliui progresuojant, hospitalizuotas ị Respublikinę Šiaulių ligoninę, atliktas rentgeninis tyrimas - nustatyta smulkiažidininè diseminacija plaučiuose. Atliktas skreplių GeneXpert tyrimas dèl tuberkuliozès mikobakterijų DNR - neaptikta. Pacientas sirgo aktyviu lètiniu virusiniu hepatitu C, naudojo tab. ribavirini $400 \mathrm{mg}$ ryte, $600 \mathrm{mg}$ vakare, bei sol. perinterferoni alfa2 $180 \mathrm{mcg} \mathrm{s} / \mathrm{c} 1 \mathrm{k} . / \mathrm{sav}$., gydymas truko $\sim 6$ mènesius. Gydymas pradètas po atliktos kepenų biopsijos, nustatyta I laipsnio fibrozé, aktyvumas 4, gydymo pradžioje HCV RNR 839000 kopijų, ALT 377 U/l, po 12sav. gydymo - viruso kopijų nerasta, ALT 28 U/1. Kreipimosi i stacionarą metu -28 gydymo ribavirinu bei pegiliuotu interferonu savaitè.

Būklè atvykus: kalbẻdamas dūsta, veide petechinis bèrimas, neryški cianozè, širdies veikla ritmiška, širdies susitraukimų dažnis 93 k./min., arterinis kraujo spaudimas 110/90 $\mathrm{mmHg}$, plaučiuose alsavimas vezikulinis, apatinèse dalyse buvo smulkių drègnų karkalų, kvėpavimo dažnis $20 \mathrm{k}$./min. kitos organų sistemos be stebimos patologijos.

Atvykus atliktas arterinio kraujo dujų tyrimas: $\mathrm{pH} 7.39$, pO2 47,7, pCO2 38,3, sO2 85,1 proc., HCO3 23,1. Kiti laboratorinių tyrimų rodikliai: CRB $66,5 \mathrm{mg} / 1$, bendras kraujo tyrimas - be patologinių pakitimų, kraujo pasèlis - neigiamas, ANA teigiamas 1:200; ANCA neigiamas, neigiamas testas dèl ŽIV, citomegalo viruso DNR neaptikta. Plaučių funkcijos tyrimai: sumažejusi plaučių talpa TLC 76 proc., sutrikusi dujų difuzija DLCO 47proc., Genslerio indeksas (FEV1/FVC) 79 proc. normos. Krūtinès ląstos rentgeninis tyrimas: miliariniai židiniai plaučiuose, gausesni viršutinèse zonose ir dešinėje (1 pav.). Atlikta kardioechoskopija - kairiojo skilvelio išstūmimo frakcija nesutrikusi, stazinio širdies nepakankamumo požymių nenustatyta. Vidaus organų echoskopijos duomenimis - vidaus organų patologijos nenustatyta. Atlikus krūtinès ląstos KT - nustatyta abiejų plaučių daugybiniai smulkūs neryškių ribų centrolobuliniai židinukai, padideję̨ tarpuplaučio limfmazgiai, nedidelis kiekis skysčio pleuros bei perikardo ertmèse, vaizdai diferencijuoti tarp bronchiolito, alerginio egzogeninio alveolito ar mikobakteriozès (2 pav.). Atlikta fibrobronchoskopija bei bronchoalveolinis lavažas (BAL), endobronchinių pakitimų nenustatyta, infekcinis sukèlejjas nenustatytas. BAL skysčio ląstelių sudètis: ląstelių skaičius 0,59 x $10 * 61$, makrofagų 18 proc., limfocitų 33 proc., neutrofilų 49 proc., navikinių ląstelių, grybų, mikrofloros, neorganinių medžiagų, Pneumocistis carinii sukèlëjo nerasta. Atlikta bronchoskopinė plaučių audinio biopsija, plaučių audinyje, alveolių spindžiuose matomi mezenchiminiai proliferatai su plazmocitine infiltracija, makrofagų židiniai. Galutinè patologijos histologinio tyrimo išvada - organizuojanti pneumonija.

Pacientui atvykus ị stacionarą buvo pradètas empirinis gydymas amoksicilinu su klavulanine rūgštimi $625 \mathrm{mg}$ x3 per os, nors simptomai neišnyko. Kai tik infekciné simptomų kilmé buvo atmesta, antibakterinis gydymas nutrauktas. Gavus plaučių audinio biopsijos rezultatus, specifinis gydymas

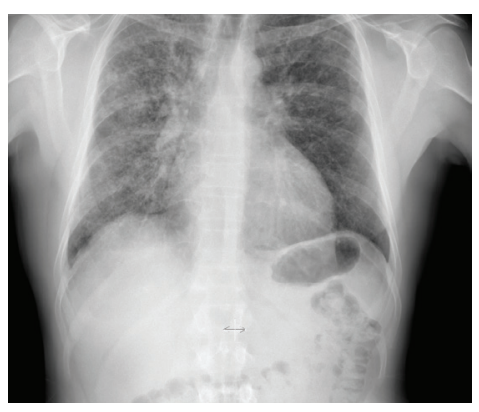

1 pav. Krūtinès ląstos rentgeninis tyrimas ligoniui atvykus: miliariniai židiniai plaučiuose, gausesni viršutinėse zonose ir dešinèje. VUL SK archyvas.

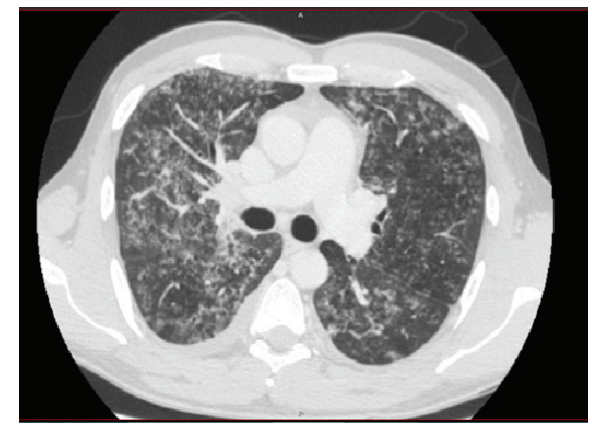

2 pav. Krūtinès ląstos kompiuterinè tomografija ligoniui atvykus: abiejuose plaučiuose smulkūs neryškių ribų centrilobuliniai židinukai; daugybinès pumpuruoto medžio tipo židinukų grupelès, padidèję tarpuplaučio limfmazgiai, nedidelis kiekis skysčio pleuros bei perikardo ertmèse. VUL SK archyvas.

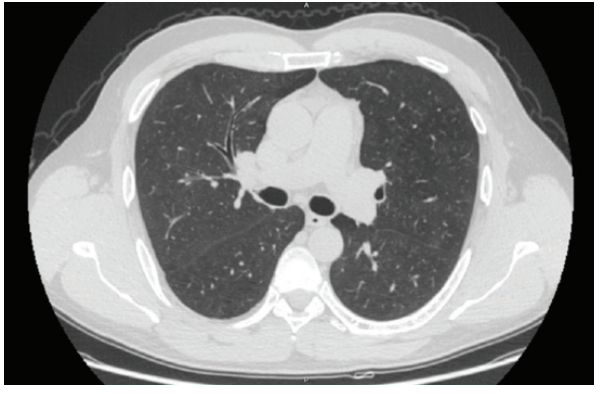

3 pav. Krūtinès ląstos kompiuterinè tomografija po 6 mènesių: patologiniai pokyčiai išnyko. VUL SK archyvas. 
ribavirinu bei pegiliuotu interferonu sustabdytas, pradètas gydymas prednizolonu $(15 \mathrm{mg} / \mathrm{d}$.). Dusulys išnyko po $1 \mathrm{mè-}$ nesio, po 6 ménesių pacientas nebejaute jokių simptomų, radiologiniai pokyčiai taip pat išnyko ( 3 pav.).

\section{Diskusija}

Diagnozuoti vaistų sukeltus plaučių pažeidimus sunku, nes dauguma atvejų ligos klinikiniai, laboratoriniai, instrumentiniai, net ir patologiniai morfologiniai simptomai yra nespecifiniai. Dèl savo didelio paviršiaus ploto plaučiai tampa taikiniu daugeliui potencialių toksinių medžiagų, kaip ir kepenys dèl daugeli fermentų apimančios sistemos, plaučiai svarbūs medikamentų biologinei transformacijai ir aktyvinimui.

Vaistų sukelti nepageidaujami poveikiai kvejpavimo takams dažnai nenustatomi, nors ir žinomi predisponuojantys veiksniai (imunosupresinès būklès pacientai, lètinèmis uždegiminėmis ligomis sergantys (reumatoidinis artritas, uždegiminès žarnų ligos), esama lètinè kvẻpavimo takų liga, vaisto dozè, kelių medikamentų, pasižyminčių pneumotoksiškumu, vartojimas vienu metu, genetiniai veiksniai) [12].

Nepageidaujamų poveikių sukeltų naudojant pegiliuoto interferono ir ribavirino derinị analizè parodè, jog kvèpavimo takų sutrikimai reti [13-15] ,dažnis iki 2-6 proc. [4]. Aprašomi organizuojančios pneumonijos, respiracinio distreso, ị sarkoidozę panašios reakcijos, bronchinès astmos paūmèjimo, plautinès hipertenzijos, skysčio pleuros ertmèse, intersticinio pneumonito klinikiniai atvejai [4].

Pirmas organizuojančios pneumonijos su obliteraciniu bronchiolitu atvejis aprašytas 1994 m. [6]. Pacientas, sergantis virusiniu hepatitu C, skundėsi dusuliu, karščiavimu ir kosuliu po 2,5 mèn. trukusio gydymo interferonu. Rentgeninio tyrimo metu nustatyti dauginiai ivvairiose srityse infiltratai plaučiuose, plaučių audinio biopsija patvirtino organizuojančios pneumonijos su obliteraciniu bronchiolitu diagnozę. Gydymas interferonu buvo nutrauktas, pradètas kortikosteroidų kursas, po keleto mėnesių kvejpavimo taku simptomai išnyko, rentgeniniai pakitimai taip pat.

Nèra nustatyta, jog ribavirinas, kuris dažniausiai skiriamas kartu su inteferonu, gali sukelti intersticinę plaučiu ligą, nors galimos nepalankios reakcijos - sausas kosulys bei dusulys [4].

OP gali sukelti ịvairios priežastys, taigi tampa sudètinga paneigti vaistų poveikį. Dažniausiai liga pasireiškia nespecifiniais simptomais: dusuliu, sausu kosuliu, subfebriliu karščiavimu, rečiau švelniu ar aštriu pleuriniu skausmu, nuovargiu, bendru silpnumu, svorio netekimu $[15,16]$. Iki 20 proc. atvejų OP nepasireiškia jokiais klinikiniais simptomais - aptinkama atsitiktinai, atlikus krūtinès ląstos rentgenini tyrimą. Auskultuojant plaučius dažniau karkalų negirdèti, rečiau girdimi pavieniai drègni smulkūs karkalai. Kraujyje būdinga nedidelè leukocitozè ir nedaug padidèjusi $\mathrm{C}$ reaktyvaus baltymo koncentracija, gali būti įvairaus laipsnio hipoksemija. Sutrinka ventiliacinė plaučiu funkcija, dažniau būdinga ịvairaus laipsnio restrikcija, rūkaliams būdinga ịvairaus laipsnio obstrukcija; galimi dujų difuzijos sutrikimai, tačiau nebūtinai.

Radiologiniai OP požymiai taip pat labai skirtingi - dauginès konsolidacijos zonos ar pritemimai skirtinguose segmentuose ar skiltyse, nuo kelių centimetrų iki visos skilties $[16,5]$. Gali būti viena konsolidacijos (pritemimo) zona arba dauginiai židiniai. Kompiuterinès tomografijos vaizduose organizuojančiai pneumonijai būdingas skirtingo intensyvumo sutankejjimas - nuo matinio stiklo iki visiškos konsolidacijos, dažniau pasitaikantis požymis - orinès bronchogramos sutankejjimo viduje $[14,12,5,16]$. Orinių bronchogramų centre kartais matomas oringas broncho spindis, rečiau atvirkštinis aureolès simptomas (matinio stiklo sutankejjimai, kurių kraštai didesnio intensyvumo).

Kai įtariama OP, visuomet reikètų atlikti bronchoalveolinį lavažą (BAL) bei bronchoskopinę plaučių audinio biopsiją. BAL skystyje būna padidèjęs limfocitų, neutrofilų ir eozinofilų kiekis, CD4/CD8 ląstelių santykis dažniausiai būna sumažèjęs. Bronchoskopinès plaučių audinio biopsijos paprastai pakanka histologiniam tyrimui, kad galima būtų patvirtinti diagnozę.

Plaučių pažeidimas, sukeltas interferono, nèra visiškai aiškus, svarstoma keletas mechanizmų. Pats vaistas turi imunomoduliuojančių savybių, manoma, jog inhibuojamos T supresinės ląstelès, aktyvuojamos citotoksinès T ląstelès, kurias indukuoja prouždegiminiai citokinai, išsiskiria didžiuliai kiekiai fibrinogeninių citokinų, kurie ir sukelia plaučių audinio fibrozę [17]. Taip pat žinoma, jog hepatito C sukèlèjas pats skatina plaučių audinio fibrozę.

Nuo 1994 m. aprašyti tik 7 interferono sukeltos organizuojančios pneumonijos atvejai [3, 7-9, 6, 10, 11] (1 lentelè).

Aprašytais atvejais visiems pacientams diagnozuotas virusinis hepatitas C (išskyrus $2008 \mathrm{~m}$. [7], kuomet pacientui atlikta kepenu transplantacija ir diagnozuota hepatoceliulinè karcinoma; $2012 \mathrm{~m}$. pacientui nustatytas ir virusinis hepatitas B [3]). Apytikslis gydymo laikas 8 savaitès - 6 mènesiai, gydymo trukme iki atsirandant simptomams nuo 6-36 savaičių. Visais atvejais pacientai gydyti pegiliuoto interferono bei ribavirino deriniu (išskyrus 1994 m. [6]). Nebuvo nustatyta jokių šalutinių ligų, galëjusių turèti ịtakos, nei lètinès plaučių ligos. Dauguma pacientų buvę rūkaliai. Visais atvejais pacientai skundèsi dusuliu bei neproduktyviu sausu kosuliu. Nustačius diagnozę, buvo nutrauktas pegiliuoto interferono bei ribavirino skyrimas, pradètas gydymas kortikosteroidais (prednizolonu ar metilprednizolonu), gydymo trukmé 
ìvairi: nuo mėnesio (aprašytu atveju) iki 6 mènesių. Visiems pacientams simptomai išnyko, patologiniai rentgeniniai pokyčiai taip pat.

OP gydoma gliukokortikosteroidais (prednizolonu ar metilprednizolonu), skelbiami ir makrolidais sèkmingai išgydytos ligos atvejai $[18,19]$, tačiau pokyčiai dažnai visiškai rezorbuojasi tik per kelis mènesius $[5,16]$. Gydymas dèl ilgalaikio steroidų vartojimo nepageidaujamo poveikio skiriamas atsižvelgiant i klinikinius bei radiologinius pokyčius - jei jie nesunkūs, o radiologiniai pokyčiai nedideli, ligonio galima negydyti, pokyčiai rezorbuojasi savaime. Jei OP sukèlè žinomas veiksnys (pvz., vaistai, cheminis aerozolis ar kt.), būtina provokuojantị veiksni nutraukti. Remiantis ligos sunkumu, skiriamas ilgalaikis gydymas geriamaisiais gliukokortikosteroidais (pradine dozé $0,75-1,5 \mathrm{mg} / \mathrm{kg}$ ). Gydoma kelis mènesius, kartais ilgiau. Nors tikètini ligos recidyvai, kuriuos vèl gali tekti gydyti, tačiau tai nedidina mirties ar ilgai trunkančio plaučių funkcijos sutrikimo tikimybès.

\section{Išvados}

1. Organizuojanti pneumonija yra reta gydymo pegiliuotu interferonu bei ribavirino deriniu komplikacija. Naujai atsiradę kvépavimo sistemos simptomai turètu būti ịvertinti ir paneigta intersticine plaučių liga. Nustačius ilgai nesirezorbuojančius infiltratus krūtinès ląstos rentgeniniame tyrime arba
1 lentelè. Organizuojančios pneumonijos, sukeltos dẻl virusinio hepatito $\mathrm{C}$ vartojamų pegiliuoto interferono bei ribavirino deriniu, atvejai.

Sutrumpinimai: VHC - virusinis hepatitas C; VHB - virusinis hepatitas B; HCC - hepatoceliuline karcinoma; IFN-interferonas; RBV-ribavirinas; GKK-gliukokortikosteroidai; MTP-metilprednizolonas; KT-kompiuterine tomografija; RO - rentgeninis tyrimas.

\begin{tabular}{|c|c|c|c|c|c|c|c|}
\hline $\begin{array}{l}\text { Šalti- } \\
\text { nis }\end{array}$ & $\begin{array}{l}\text { Virusas, } \\
\text { genotipas }\end{array}$ & $\begin{array}{c}\text { Gydymo } \\
\text { trukmé } \\
\text { iki } \\
\text { simp- } \\
\text { tomų }\end{array}$ & $\begin{array}{c}\text { Krūt. } \\
\text { ląstos RO }\end{array}$ & Krūt.ląstos KT & $\begin{array}{c}\text { Biop- } \\
\text { sija }\end{array}$ & $\begin{array}{c}\text { Gydymas, } \\
\text { trukmé }\end{array}$ & Baigtis \\
\hline 6 & VHC & 8 sav. & $\begin{array}{c}\text { Smulkūs } \\
\text { infiltratai, } \\
\text { retikuliniai } \\
\text { patamsejji- } \\
\text { mai }\end{array}$ & - & + & $\begin{array}{c}\text { Savaiminis } \\
\text { simptomų } \\
\text { išnykimas } \\
\text { nutraukus } \\
\text { IFN+RBV }\end{array}$ & $\begin{array}{c}\text { Simptomai } \\
\text { išnyko po } 1 \\
\text { sav. }\end{array}$ \\
\hline 8 & VHC, 1B & 6 sav. & $\begin{array}{c}\text { Interstici- } \\
\text { nio audinio } \\
\text { sutan- } \\
\text { kejjimas } \\
\text { bazalinèse } \\
\text { dalyse } \\
\end{array}$ & $\begin{array}{c}\text { Difuziniai } \\
\text { matinio stiklo } \\
\text { infiltratai }\end{array}$ & + & $\begin{array}{c}1 \mathrm{mg} / \mathrm{kg} / \mathrm{d} . \\
6 \mathrm{mèn} . \\
\text { GKK }\end{array}$ & $\begin{array}{l}\text { RO poky- } \\
\text { čiai išnyko } \\
\text { po } 9 \text { mèn. }\end{array}$ \\
\hline 7 & $\begin{array}{c}\text { VHC, } \\
\text { HCC, } \\
\text { kepenų } \\
\text { transplanta- } \\
\text { cija, 2A/2C }\end{array}$ & 8 sav. & $\begin{array}{c}\text { Kairios } \\
\text { viršutinės } \\
\text { skilties } \\
\text { infiltracija }\end{array}$ & $\begin{array}{l}\text { Dešinės apatinės } \\
\text { skilties bron- } \\
\text { chektazės, skystis } \\
\text { pleuros ertmėse, } \\
\text { viršutinių skilčių } \\
\text { intersticiniai } \\
\text { infiltratai }\end{array}$ & - & $\begin{array}{c}1 \mathrm{mg} / \mathrm{kg} / \mathrm{d} . \\
\mathrm{MTP} 3 \\
\text { mèn. }\end{array}$ & $\begin{array}{l}\text { Po } 1 \text { mèn. } \\
\text { išnyko } \\
\text { pakitimai } \\
\text { KT }\end{array}$ \\
\hline 9 & VHC, 1B & 36 sav. & $\begin{array}{l}\text { Abipus pa- } \\
\text { tamsèjimai } \\
\text { apatinèse } \\
\text { srityse }\end{array}$ & $\begin{array}{c}\text { Matinio stiklo } \\
\text { vaizdas, abipus } \\
\text { dauginiai konsoli- } \\
\text { dacijos plotai }\end{array}$ & + & $\begin{array}{l}1 \mathrm{mg} / \mathrm{kg} \\
\mathrm{GKK}, \\
6 \text { mèn. }\end{array}$ & Pasveiko \\
\hline 3 & $\begin{array}{l}\text { VHC, } \\
\text { VHB, } 3\end{array}$ & 15 sav. & & $\begin{array}{c}\text { Mozaikinis } \\
\text { plaučių audinio } \\
\text { sutankèjimas }\end{array}$ & - & $\begin{array}{c}30 \mathrm{mg} / \mathrm{d} . \\
\text { GKK }\end{array}$ & $\begin{array}{l}\text { Simptomai } \\
\text { išnyko per } \\
2 \text { sav., KT - } \\
\text { po } 12 \text { mèn. }\end{array}$ \\
\hline 10 & VHC, $1 \mathrm{~A}$ & 28 sav. & $\begin{array}{c}\text { Dauginiai } \\
\text { infiltratai } \\
\text { abipus }\end{array}$ & $\begin{array}{c}\text { Plaučių audinio } \\
\text { konsolidacijos } \\
\text { plotai abipus }\end{array}$ & + & $\begin{array}{c}30 \mathrm{mg} / \mathrm{d} . \\
\text { GKK }\end{array}$ & $\begin{array}{c}\text { Simptomai } \\
\text { išnyko po } \\
2 \text { mèn. } \\
\end{array}$ \\
\hline 11 & VHC & 13 sav. & $\begin{array}{l}\text { Retikuli- } \\
\text { niai patam- } \\
\text { sejjimai }\end{array}$ & $\begin{array}{l}\text { Matinio stiklo } \\
\text { plotai abipus }\end{array}$ & + & $\begin{array}{c}30 \mathrm{mg} / \mathrm{d} . \\
\text { GKK } 3 \\
\text { mèn. }\end{array}$ & Pasveiko \\
\hline $\begin{array}{l}\text { Atpa- } \\
\text { riamas } \\
\text { klini- } \\
\text { kinis } \\
\text { atvejis }\end{array}$ & VHC, 1 & 28 sav. & $\begin{array}{c}\text { Smulkia- } \\
\text { židininé } \\
\text { disemina- } \\
\text { cija }\end{array}$ & $\begin{array}{c}\text { Intersticiné } \\
\text { plaučių audinio } \\
\text { infiltracija, } \\
\text { tarpuplaučio } \\
\text { limfadenopatija, } \\
\text { nedidelis kiekis } \\
\text { skysčio pleuros ir } \\
\text { perikardo ertmèse }\end{array}$ & + & $\begin{array}{c}15 \mathrm{mg} / \mathrm{d} .1 \\
\text { mèn }\end{array}$ & $\begin{array}{c}\text { Simptomai } \\
\text { išnyko po } \\
1 \text { mèn.. KT } \\
\text { pakitimai } \\
\text { išnyko po } 6 \\
\text { mèn. }\end{array}$ \\
\hline
\end{tabular}

santykinai lengvus klinikinius simptomus esant didelès apimties plaučiu rentgeniniams pokyčiams (aiškių ribų plaučių pritemimai skirtinguose plaučių segmentuose ar skiltyse, matinio stiklo vaizdas), reikètų atlikti fibrobronchoskopiją, bronchoalveolinį lavažą bei bronchoskopinę plaučių audinio biopsiją.

2. Daugumos literatūroje aprašomų atvejų baigtys geros, prognozė palanki. Liga dažnai trunka iki 3 mènesių, gydant steroidais (o kartais ir savaime) patologiniai pokyčiai beveik visuomet išnyksta be liekamujų reiškinių.

3. OP turètų būti įtarta virusiniu $C$ hepatitu sergantiems pacientams, gydomiems pegiliuotu interferonu ir ribavirinu, kuriems atsirado naujų kvėpavimo sistemos simptomų. 


\section{Literatūra}

1. Slavenburg S, Heijdra YF, Drenth JPH. Pneumonitis as a consequence of (Peg) interferon-ribavirin combination therapy for hepatitis C: a review of the literature. Digestive Diseases and Sciences 2010; 55(3):579-585.

https://doi.org/10.1007/s10620-009-0797-1

2. Ji F-P, Li Z-X, Deng H, Xue H-A, Liu Y, Li M. Diagnosis and management of interstitial pneumonitis associated with interferon therapy for chronic hepatitis C. World Journal of Gastroenterology, WJG 2010; 16(35):4394-4399.

https://doi.org/10.3748/wjg.v16.i35.4394

3. Hegade VS, Sood R, Saralaya D, Moreea S. et al. Pulmonary complications of treatment with pegylated interferon for hepatitis C infection - two case reports. Annal of Hepatol 2013; 12(4):431-465.

4. Midturi J, Sierra-Hoffman M, Harley D. et al. Spectrum of pulmonary toxicity associated with the use of interferon therapy for hepatitis C: case report and review of literature. CID 2004; $39: 1724-9$.

https://doi.org/10.1086/425746

5. Schwaiblmair M, Behr W, Haeckel T. et al. Drug induced interstitial lung disease. The Open Resp Med J, 2012; 6:63-74. https://doi.org/10.2174/1874306401206010063

6. Ogata K, Koga T, Yagawa K. Interferon related bronchiolitis obliterans organizing pneumonia. Chest 1994;106(2):612-613. https://doi.org/10.1378/chest.106.2.612

7. Crespi C, Gualandi S, Piscaglia F. et al. Onset of bronchiolitis obliterans organizing pneumonia in a liver transplant under peginterferon and ribavirin treatment. Inter E,erg Med 2008; 3:77-80.

https://doi.org/10.1007/s11739-008-0098-2

8. Trullas Vila JC, Padilla López DR, Bisbe Company V. et al Organizing pneumonia associated with the use of pegylated interferon alfa. Arch Bronconeumol 2008; 44(3):173-4. https://doi.org/10.1157/13116606

9. Martins RS, Machado JA, Teixeira R. Secondary bronchiolitis obliterans organizing pneumonia during treatment of chronic hepatitis $\mathrm{C}$ with pegylated interferon alfa-2a. Revista da Sociedade Brasileira de Medicina Tropical 2012; 45(5); 655-656. https://doi.org/10.1590/S0037-86822012000500023

10. Krorashad A K, Tohidi M, Vosoughinia H. et al. A case report of pegylated interferon and bronchiolitis obliterans with organizing pneumonia. Govaresh 2012; 17:125-8.

11. Chung E, Park K, Kim JH. et al. Korean J Intern Med 2017; 32(6):1098-1100.

https://doi.org/10.3904/kjim.2013.124

12. Matsuno O. Drug induced interstitial lung disease: mechanisms and best diagnostic approcaches. Resp R 2012; 5:13-39. https://doi.org/10.1186/1465-9921-13-39

13. Fried MW, Shiffman ML, Reddy R. et al. Peginterferon alfa- $2 b$ plus ribavirin for chronic hepatitis $\mathrm{C}$ virus infection. $\mathrm{N}$ Engl $\mathrm{J}$
Med 2002; 347(13):975-982.

https://doi.org/10.1056/NEJMoa020047

14. Camus PH, Foucher P, Bonniaud PH. et al. Drug induced infiltrative lung disease. Eur Respir J 2001: 18(32):93-100.

15. Camus P, Fanton A, Bonniaud P. et al. Interstitial lung disease induced by drugs and radiation. Respiration 2004; 71:301-326. https://doi.org/10.1159/000079633

16. Rossi SE, Erasmus J, Page H. et al. Pulmonary drug toxicity: radiologic and pathologic manifestations. RadioGraphics 2000; 20:1245-1259.

https://doi.org/10.1148/radiographics.20.5.g00se081245

17. Abi-Nassif S, Mark EJ, Fogel R. et al. Pegylated interferon and ribavirin induced interstitial pneumonitis with ARDS. Chest 2013; 124: 406-410.

https://doi.org/10.1378/chest.124.1.406

18. Radzikowska E, Rozy A, Jagus P. et al. Clarythromycin decreases IL-6 concentrations in serum and BAL fluid in patient with cryptogenic organizing pneumonia. Adv Clin Exp Med 2016; 25(5): 871-878. https://doi.org/10.17219/acem/61953

19. Pathak V., Kuhn JM, Durham C. et al. Macrolide use leads to clinical and radiological improvement in patients with cryptogenic organizing pneumonia. Ann Am Thorac Soc 2014; 11(1): 87-91.

https://doi.org/10.1513/AnnalsATS.201308-261CR

\section{ORGANIZING PNEUMONIA. CASE REPORT \\ E.Bagurskienè, R.Zablockis}

Key words: organizing pneumonia, obliterative bronchiolitis with organizing pneumonia, drug induced interstitial lung disease, pegylated interferon, viral hepatitis $\mathrm{C}$.

Summary

Organizing pneumonia (OP) is an interstitial lung disease characterized by the formation of mesenchymal proliferates in the alveoli in a limited part of the lungs or in several separate sites. The incidence of this disease is not clear. The OP may be of unknown origin (cryptogenic) or associated with another disease or pathological condition (caused by medicines, toxins, inflammatory autoimmune diseases, tumors, radiotherapy, etc.). Symptoms of the disease are not specific, may include febrile fever, dry, nonproductive cough, dyspnea. Often, the clinical course is mild, and in rare cases, dyspnea, respiratory failure, progresses. Radiological signs of OP are diverse - clear limits of lung consolidations in different segments or lobes. The diagnosis is confirmed by a morphological examination of a bronchoscopic pulmonary tissue biopsy. In case of mild illness, treatment is not given. In more severe cases, the OP is treated with glucocorticosteroids (prednisolone or methylprednisolone), but the symptoms disappear and the X-rays often completely absorb within a few months.

Correspondence to: ernesta.gr@gmail.com

Gauta 2018-10-15 